\title{
Phosphorus Retention of a Permeable Reactive Barrier Surpassed by an Unvegetated Artificial Pond
}

\author{
Robert Summers ${ }^{1} \&$ David Weaver ${ }^{2}$ \\ ${ }^{1}$ Department of Primary Industries and Regional Development, Western Australia, 45 Mandurah Terrace, Western \\ Australia \\ ${ }^{2}$ Department of Primary Industries and Regional Development, Western Australia, 444 Albany Highway, Western \\ Australia \\ Correspondence: Robert Summers, Department of Primary Industries and Regional Development, Western \\ Australia, 45 Mandurah Terrace, Western Australia 6215. E-mail: robert.summers@dpird.wa.gov.au
}

Received: August 30, 2021

Accepted: November 9, $2021 \quad$ Online Published: December 9, 2021

doi:10.5539/enrr.v11n1p25

URL: https://doi.org/10.5539/enrr.v11n1p25

\begin{abstract}
An artificial pond bisected by a phosphorus (P) retentive permeable reactive barrier (PRB) alongside Forrest Highway, Coolup, Western Australia was designed to remove P from farmland runoff. The pond bed was made of subsoil and road construction materials likely to have a relatively high $\mathrm{P}$ sorption capacity, and there was no vegetation in the bed of the pond. Flow through the pond was intercepted by the PRB, constructed from a mixture of sand, coarse crushed limestone, and bauxite residue (with 10\% phospho-gypsum). The effectiveness of $\mathrm{P}$ removal and the impact of the PRB was measured by comparing the concentration of contaminants immediately either side of the PRB with established standards, and against background levels in runoff from surrounding farmland. Using coarse limestone to increase flow through the PRB failed where permeability was insufficient to avoid overtopping of the PRB and the wall had to be lowered to allow by-pass and avoid collapse. The PRB was effective in removing total P (TP); however, the influent TP concentration was low (mean $0.19 \mathrm{mg}$ $\mathrm{L}^{-1}$ ) because most $\mathrm{P}$ entering from farmland was retained in the shallow pond upstream of the PRB. Despite this, TP removal by the PRB was 53\% (2009-2012). Occasionally, in spring when the pond was stagnant and anaerobic, $\mathrm{P}$ was released from the PRB. This minor P release coincided with a minor release of iron, consistent with anaerobic conditions found in the PRB. Although not designed to do so, the shallow pond upstream of the PRB reduced the TP concentration from farmland by $85 \%$ (mean $1.26 \mathrm{mg} \mathrm{L}^{-1}$ down to $0.19 \mathrm{mg} \mathrm{L}^{-1}$ ), mainly by reducing filterable reactive $\mathrm{P}$ concentration. Some elements (arsenic, cobalt, conductivity, fluoride, manganese, molybdenum, $\mathrm{pH}$, selenium, uranium and vanadium) were increased by flow through the PRB, but were low relative to surrounding waters and environmental standards.
\end{abstract}

Keywords: permeable reactive barrier, bauxite residue, artificial pond, phosphorus retention, water quality

\section{Introduction}

Water quality in coastal estuarine systems in Western Australia (WA) is affected by phosphorus (P) that drains from sandy coastal catchments (Hodgkin \& Hamilton, 1993). The Peel Inlet and Harvey Estuary (Peel-Harvey) is one catchment under stress from algal blooms driven by high $\mathrm{P}$ content in water draining from the surrounding area (McComb \& Humphries, 1992). Amending soils with nutrient-retentive material on farmland in the PeelHarvey catchment has been shown to be effective to retain P (R. Summers, Guise, Smirk, \& Summers, 1996 ; R. Summers, Richards, Weaver, \& Rowe, 2020; R. Summers, Smirk, \& Karafilis, 1996; Ward \& Summers, 1993). Although soil amendment is an effective P retention practice, it is not applicable to all soils and is not widely adopted, because of issues of access, cooperation, investment from landholders, and government approvals.

Soil amendment tackles the loss of $\mathrm{P}$ at source; however, there are other points of intervention and practices for nutrient reduction beyond the edge of farm fields (Gourley \& Weaver, 2012). Although streambed sediment has been shown to retain P (Clarendon, Weaver, Davies, \& Coles, 2019), retention using downstream practices to further improve P removal from drainage waters in WA is poorly understood. In addition, it can be difficult to draw direct comparisons from studies in other areas due to differences in hydrology that are affected by the sandy catchment and the influence of groundwater in coastal catchments in WA (Barron, Donn, Pollock, \& Johnstone, 2010). 
PRBs constructed from P retentive materials have been shown to be effective at removing P (Drizo, Frost, Grace, \& Smith, 1999), but performance is reliant on maintaining permeability. PRBs have particular application for retaining $\mathrm{P}$ from runoff in coastal WA because $\mathrm{P}$ transport is dominated by soluble fractions, low suspended solids, and retention of $\mathrm{P}$ is mainly through sorption by wetland substrate rather than vegetative uptake (R. Summers, Weaver, Keipert, \& Steele, 2014; Weaver \& Summers, 2014). P-retentive media (such as cracked lateritic gravel) was effective in field trials when applied to the base of a drain, but only for the first year due to the limited retention capacity of the coarse gravel and was less effective at retaining $\mathrm{P}$ than freshly excavated stream sediment (26 and 55\% filterable reactive P (FRP) removal respectively) (R. Summers et al., 2014).

Increasing the interaction of coastal drainage through passive filtration and by actively pumping water through media constructed from by-products of mineral sands processing has resulted in high $(>90 \%) \mathrm{P}$ removal efficiency (ChemCentre, 2012; Wendling, Douglas, Coleman, Yuan, \& Klauber, 2010); however, permeability decline through PRB blockage and blinding significantly reduced flow rate (Barron et al., 2010). These previous studies used deep PRB media that included a fine particulate by-product and only added coarse sand to improve permeability, which may have contributed to reduced flows by dislodging and accumulating fine particulates, and thus blocking flow.

Field testing is required to examine whether the potential media applied to the base is a sink or source of $\mathrm{P}$ depending on the conditions in a wetland. A study of media used in an artificial wetland found it could retain P in laboratory tests but was ineffective in the wetland due to in-situ effects operating in the pore waters of the media (Palmer-Felgate, Bowes, Stratford, Neal, \& MacKenzie, 2011). Flow conditions can also affect P retention effectiveness due to residence time influencing the interaction of contaminants with media, and settling of particulates, thus making it difficult to predict water quality outcomes (Reinhardt, Gachter, Wehrli, \& Muller, 2005; Woltemade, 2000). Characteristics of wetland substrates and PRB media such as equilibrium P concentration $\left(\mathrm{EPC}_{0}\right)$, along with influent $\mathrm{P}$ concentrations can also influence whether the substrate or media will behave as a source or sink of P (Froelich, 1988; Lucci, McDowell, \& Condron, 2010; Taylor \& Kunishi, 1971). When influent $\mathrm{P}$ concentrations exceed the $\mathrm{EPC}_{0}$ value of the substrate or media, the substrate or media is likely to retain $\mathrm{P}$. When influent $\mathrm{P}$ concentrations are less than the $\mathrm{EPC}_{0}$ value of the substrate or media, the substrate or media is likely to become a source of P. Hence the degree to which the wetland substrate or media has been exposed to $\mathrm{P}$ previously, along with concentration of $\mathrm{P}$ that drains into the wetland will contribute to wetland performance.

P sorption methods have been used to screen substrates for P removal (Drizo et al., 1999) as well as the use of single point $P$ sorption isotherm techniques commonly used in agronomy (Allen \& Jeffery, 1990; Bolland, Gilkes, Brennan, \& Allen, 1996; Burkitt, Moody, Gourley, \& Hannah, 2002) but P sorption relies on the media being in intimate contact with the effluent for sufficient time. Laboratory procedures to determine P sorption do not take account of in-situ factors that restrict contact such as smothering or coating of sediment and blockage of media.

Bauxite residue - a by-product of alumina refining - has been demonstrated to retain $\mathrm{P}$ when used as a soil amendment (R. Summers, Guise, et al., 1996; R. Summers, Smirk, et al., 1996; Ward \& Summers, 1993), when applied at $20 \mathrm{t} / \mathrm{ha}$ or less, usually in aerobic conditions, and under the $\mathrm{pH}$ conditions of treated soils (often less than a pH of 5) (R. Summers, Bolland, \& Clarke, 2001; Weaver \& Summers, 2013). Soil amendment is not always applicable or accepted, and other practices such as a PRB for use standalone or in conjunction with other practices can be used to process $P$ enriched runoff when it has entered the drainage system.

This study investigates a PRB in a pond constructed from $12 \%$ bauxite residue to test whether it would allow sufficient flow to avoid overtopping the PRB, and how effectively the PRB media would remove P. The bauxite residue has a particle size similar to a silty clay and was combined with coarse sand, coarse limestone, and gypsum to improve flow.

An important subsidiary aim was to determine the nature of any contaminants that may be leached from the PRB media. Since bauxite residue is the result of treatment of finely ground laterite with caustic soda to remove the aluminium, the relative proportion of potential contaminants in the residue increases. The extraction process has the potential to solubilize contaminants which include metals (Carter, Van der Sloot, \& Cooling, 2009; Van der Sloot et al., 2003) or radioisotopes (Mcpharlin, Jeffery, Toussaint, \& Cooper, 1994; K. Summers, O'Connor, \& Fox, 1993) derived from the granitic base of the ore which contains uranium and thorium. Previous leaching studies (Carter et al., 2009; Van der Sloot et al., 2003) on WA bauxite residue were sourced directly from the Bayer process combined with local soil for soil amendment (Carter et al., 2009; Van der Sloot et al., 2003), but not as a PRB media in conjunction with local soil, limestone and gypsum. The addition of these components may affect the final $\mathrm{pH}$ and the solubility of the elements, and thus requires investigation. 


\section{Method}

\subsection{Pond Layout}

An artificial pond was constructed alongside Forrest Highway in Coolup, WA during the highway's construction in 2009. A PRB of P-retentive media made from bauxite residue and limestone was placed across the widest point of the pond. The pond was designed to process water from adjacent farmland that drained into the Mayfield drain, which then drained into the Peel-Harvey estuarine system.

Table 1. Major Constituents and Particle Size of PRB Components (\% w/w)

\begin{tabular}{cccc}
\hline & Bauxite residue & Sand & Limestone \\
\hline & & Constituents & \\
$\mathrm{Al}_{2} \mathrm{O}_{3}$ & 22 & 0.15 & \\
$\mathrm{Fe}_{2} \mathrm{O}_{3}$ & 28 & 0.21 & 19 \\
$\mathrm{SiO}_{2}$ & 27 & 98 & \\
$\mathrm{CaO}$ & 4.4 & & 76 \\
$\mathrm{Na}_{2} \mathrm{O}$ & 2.6 & & \\
$\mathrm{CaCO}_{3}$ & & & \\
$\mathrm{MgCO}_{3}$ & & & \\
& & & \\
\hline $0.000-0.125$ & 20.1 & & \\
$0.125-0.250$ & 6.6 & 5 & \\
$0.250-0.500$ & 8.8 & 46 & \\
$0.500-1.000$ & 11.7 & 48 & \\
$1.000-2.000$ & 52.7 & & \\
$2.000-25.000$ & & & \\
\hline
\end{tabular}

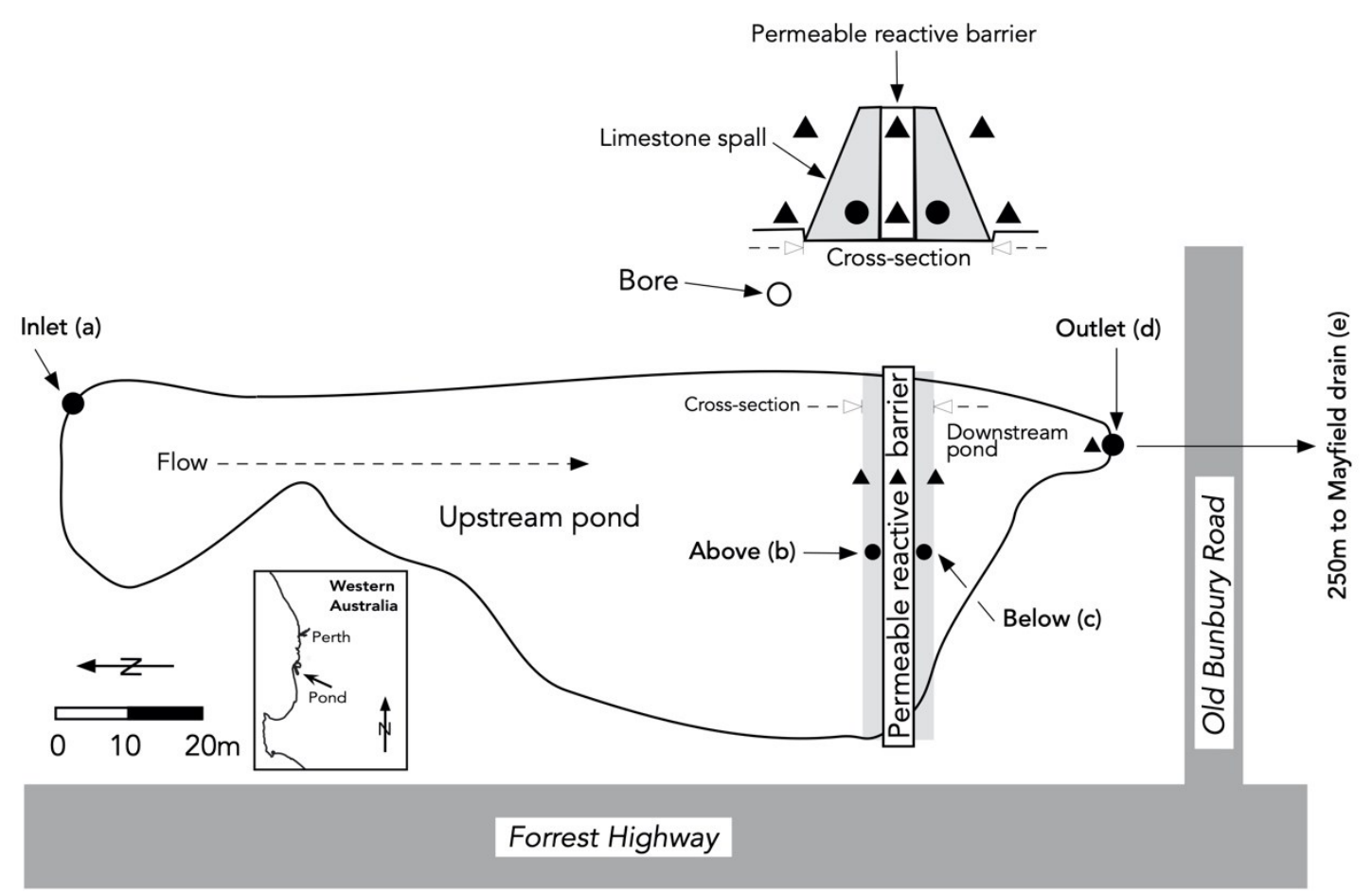

Figure 1. Location of the sampling points in the artificial pond and expanded view of cross section. Sampling points labelled as (a) to (e) shown as filled circles and dissolved oxygen measuring points shown as filled triangles (displaced for clarity). 
The pond was $175 \mathrm{~m}$ long and $50 \mathrm{~m}$ wide at the widest point. The PRB was constructed from plastic leach drain baskets filled with a PRB media (Table 1) made from $5 \mathrm{~m}^{3}$ (12\%) RMG10 (bauxite residue supplied from Alcoa World Alumina Australia, Kwinana operations with 10\% phospho-gypsum a by-product of fertiliser manufacture from CSBP), $5 \mathrm{~m}^{3}$ (12\%) coarse clean sand from the site (48\% 0.5-1 mm; 46\% 0.18-0.5 mm; 5\% 0.063-0.18 mm; $0.9 \%<0.63 \mathrm{~mm})$, and $33 \mathrm{~m}^{3}(76 \%)$ coarse crushed limestone - screened 2 to $25 \mathrm{~mm}$. The baskets were assembled into a $52 \mathrm{~m}$ long, $0.9 \mathrm{~m}$ thick, and $1.2 \mathrm{~m}$ high wall surrounded by geotextile (Figure 1). The wall was constructed in a $0.15 \mathrm{~m}$ deep trench on a plastic membrane to prevent runoff water from upstream bypassing below the PRB. The remainder of the base of the pond remained uncovered. The PRB baskets were additionally stabilised with a coarse limestone-spall (50 to $200 \mathrm{~mm}$ ) tapered buttress with two high-flow overflow points near its centre. The limestone spall was additional and external to the media contents of the PRB.

A 90 degree sharp-crested V-notch weir made from steel plate was installed with an overflow set at $300 \mathrm{~mm}$ above the base of the pond (Bos, 1989). In early monitoring (August 2009), the pond upstream of the PRB rose to $1.2 \mathrm{~m}$ deep during high flows and breached the PRB wall, damaging the bank adjacent to the highway. The PRB height was then lowered to $900 \mathrm{~mm}$. A PVC slotted-pipe bore was installed to the east and adjacent to the weir to compare the groundwater level with the level in the pond.

\subsection{Sampling and Flow Monitoring}

From July 2009 to September 2012 water samples were collected from the inlet of the pond (a); immediately above (b) and below the PRB (c) (inside the limestone spall against the PRB baskets); at the V-notch weir outlet of the pond (d); and in the Mayfield drain (e) immediately upstream of the point where the runoff from the pond enters the drain (Figure 1). Following the onset of flow (20 July 2009), all sites were sampled manually and automatically for 72 hours (4 samples every 24 hours) by ISCO automatic samplers immediately above (b, upstream) and below (c, downstream) the PRB and at the V-notch weir (d). The ISCO automatic samplers were later programmed to take one sample every day (comprising 6 subsamples) for the remainder of 2009. From 2010, the automatic samplers were not used, and samples were collected manually from the same locations using the manual mode of the automatic samplers. Purging of the sampling line occurred before each sample was collected.

Flow monitoring was achieved using flow modules on the ISCO autosamplers placed in flow control structures. These included an area velocity doppler flow meter in a square-section inverted concrete culvert at the pond inlet (a), and a bubbler depth-gauge at the V-notch weir at the pond outlet (d).

Samples were analysed for the concentration of metals, contaminants, and nutrients across the pond and through the PRB. Water flow was monitored for 6 months from mid-June 2009 to the beginning of January 2010. Separate subsamples were retained for total elemental analysis and for soluble elemental analysis, where the latter were filtered using a $0.45 \mu \mathrm{m}$ filter before being analysed for metals and other contaminants.

Quality assurance samples including field blanks (samples of distilled water taken into the field and opened next to the sampling equipment during sampling to assess contamination from handling, dust or other volatile contamination), a spike, and replicate samples were also taken at each sampling.

\subsection{Alpha and Beta Emissions}

Gross alpha and beta emissions (Nelson, 2003) were determined on a composite sample collected between 20-24 July 2009, and a single sample collected 5 November 2009. Emissions were analysed from samples evaporated at $105{ }^{\circ} \mathrm{C}$. These analyses included a correction for potassium emissions and an assessment of emissions from the filtrate.

\subsection{Analytes}

All analytes were measured at the beginning of the trial. The list of analytes was reviewed periodically, and by the last year of the trial only a key number of analytes were being monitored.

Water samples were analysed based on methods published by Eaton, Clesceri, Rice, Greenberg, and Franson (2005) with method numbers shown in parentheses.

F in water by ion specific electrode ((Eaton et al., 2005): 4500F-C).

Total metals by digestion (USEPA 3015a microwave digest) and ICP-AES ((Eaton et al., 2005): 3120) Al, Ag, As, $\mathrm{Ba}, \mathrm{Be}, \mathrm{B}, \mathrm{Ca}, \mathrm{Cd}, \mathrm{Co}, \mathrm{Fe}, \mathrm{Mg}, \mathrm{Mo}, \mathrm{Ni}, \mathrm{Pb}, \mathrm{Se}, \mathrm{Sn}, \mathrm{Sr}$, Th, U, V and Zn. Hg CV-AAS ((Eaton et al., 2005): 3112)

$\mathrm{Cr}$ and (VI) by colorimetric analysis by discrete autoanalyser ((Eaton et al., 2005): 3500-Cr B) 
Total Nitrogen (TN) by persulfate digestion FIA ((Eaton et al., 2005): 4500N-C,I)

Nitrate-Nitrite $\left(\mathrm{NO}_{3}-\mathrm{N}\right)$ expressed as N by FIA ((Eaton et al., 2005): $\left.4500 \mathrm{NO}_{3}-\mathrm{I}\right)$

Soluble reactive $\mathrm{P}$ in water by FIA ((Eaton et al., 2005): 4500P-G)

pH in water by $\mathrm{pH}$ meter ((Eaton et al., 2005): 4500H+)

Total phosphorus (TP) by persulfate digestion and FIA ((Eaton et al., 2005): P-J,G)

Total suspended solids (TSS) ((Eaton et al., 2005): 2540D)

Electrical conductivity (EC) in water @ $25^{\circ} \mathrm{C}$ (APHA 2510B).

Dissolved oxygen (DO) was measured at each site shown in Figure 1 on 6 mornings between 10 September and 15 October 2009, using a handheld, multiple-probe, Hydrolab Surveyor 4a with a Minisonde MS5 probe. Measurements were taken after the readings stabilized while the probe was gently agitated, in the open pond above and below the PRB, from an access tube within the PRB and the weir at the pond outlet. At each site the DO was measured either at the base of the pond (or PRB) and $100 \mathrm{~mm}$ below the surface.

\subsection{Statistics}

Data was analysed and presented using Igor Pro V8 from WaveMetrics, Inc. A Student's t-test was carried out assuming unequal variances to assess the probability of a difference between paired samples from each monitoring site.

\section{Results}

\subsection{Flow Monitoring}

The pond began filling with water before runoff from the adjacent paddock entered the pond. Water depth measured in the pond prior to runoff correlated with the watertable of a monitoring bore up-gradient of the pond (Figure 1).

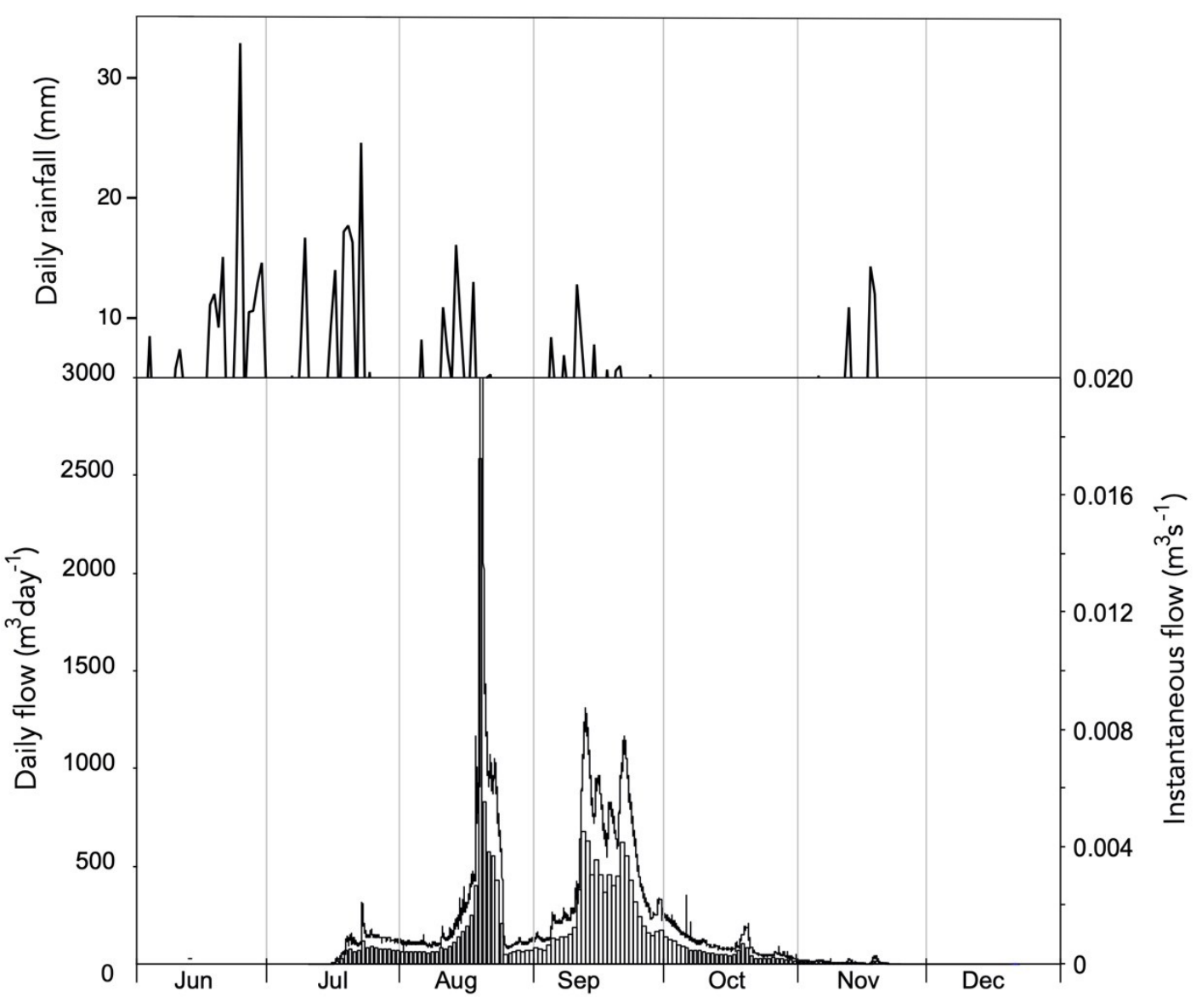

Figure 2. Flow at the outlet of the pond in 2009: daily flow (bars) overlying instantaneous flow rate (trace), daily rainfall in upper panel. 
During the 6-month flow period in 2009, $19690 \mathrm{~m}^{3}$ of water flowed over the weir at the pond outlet (Figure $1 \mathrm{~d}$ ). Up until the overflow of the PRB (19 August 2009) $3359 \mathrm{~m}^{3}$ flowed over the weir, during the breach (19-24 August 2009) $4870 \mathrm{~m}^{3}$ flowed over the weir, and after this period $11461 \mathrm{~m}^{3}$ flowed over the outlet weir (Figure 2 ). The pond filled to varying depths depending on rainfall and seasonal inflows. During summer, it dried completely, and during winter the downstream pond filled and flowed over the V-notch weir.

\section{$3.2 P$ and $N$}

The TP and FRP concentration fell between the pond inlet (Figure $1 \mathrm{a}$ ) and the monitoring point above the PRB (Figure $1 \mathrm{~b}$ ) by $85 \%$ (mean 1.26 to $0.19 \mathrm{mg} \mathrm{L}^{-1}$ ) and $96 \%$ (mean 0.998 to $0.087 \mathrm{mg} \mathrm{L}^{-1}$ ) respectively from 2009 to 2012 (Figure $3 \mathrm{a}, \mathrm{b})$.
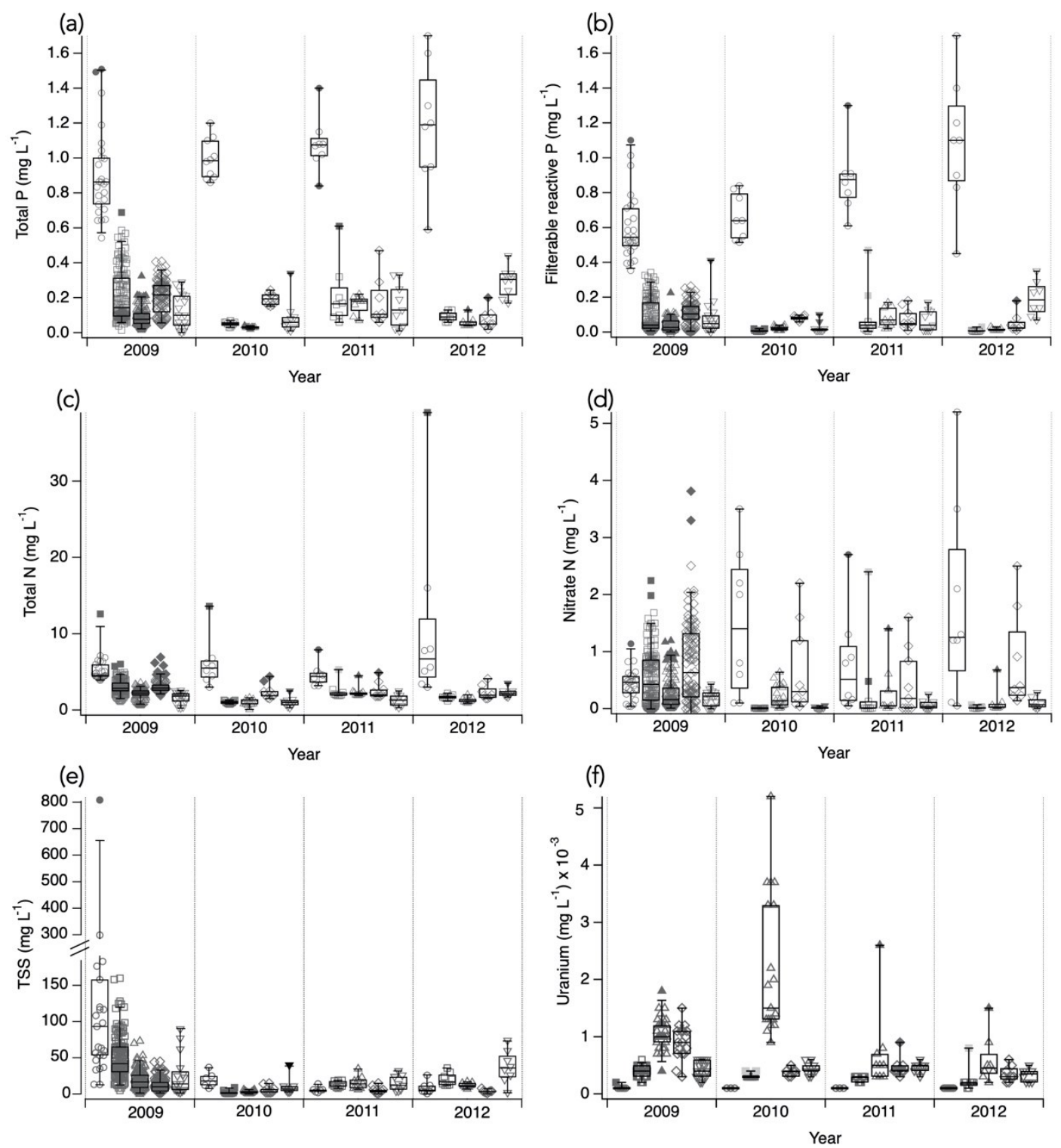

Figure 3. Water analytes throughout the pond from 2009 to 2012 shown as box and whisker plots for (a) TP, (b) FRP, (c) Total N, (d) Nitrate N, (e) TSS, (f) U. The location of sampling points for each year are from left to right: circles - inlet to the pond (Figure $1 \mathrm{a}$ ); squares - immediately upstream of the PRB (Figure $1 \mathrm{~b}$ ); triangles immediately downstream of the PRB (Figure $1 \mathrm{c}$ ); diamonds - at the outlet of the pond (Figure $1 \mathrm{~d}$ ); inverted triangles - in the Mayfield drain immediately upstream of the entry point from the pond drainage (Figure $1 \mathrm{e}$ ). 
The $\mathrm{TN}$ and $\mathrm{NO}_{3}-\mathrm{N}$ concentration fell between the pond inlet (Figure $1 \mathrm{a}$ ) and the monitoring point above the PRB (Figure $1 \mathrm{~b}$ ) by $66 \%$ ( 8.15 to $2.76 \mathrm{mg} \mathrm{L}^{-1}$ ) and $89 \%$ (4.12 to $0.45 \mathrm{mg} \mathrm{L}^{-1}$ ) respectively, from 2009 to 2012 (Figure $3 \mathrm{c}, \mathrm{d})$. There was no trend between years for the $\mathrm{P}$ or $\mathrm{N}$ forms across the PRB.

TP and FRP concentration generally decreased across the PRB (from above to below), but towards the end of 2009 and 2011 when flow and $\mathrm{P}$ concentration above the PRB was low, P concentrations increased, and P removal was negative (Figure 4). The mean TP and FRP removal across the PRB were $53 \%\left(0.193\right.$ to $\left.0.090 \mathrm{mgL}^{-1}\right)$ and $55 \%$ ( 0.087 to $0.039 \mathrm{mg} \mathrm{L}^{-1}$ ) respectively. The $\mathrm{TN}$ and $\mathrm{NO}_{3}-\mathrm{N}$ concentration fell across the PRB by $27 \%$ (2.76 to 2.01 $\left.\mathrm{mg} \mathrm{L}^{-1}\right)$ and $46 \%\left(0.449\right.$ to $\left.0.242 \mathrm{mg} \mathrm{L}^{-1}\right)$ respectively, between 2009 and 2012 (Figure $3 \mathrm{c}, \mathrm{d}$ ). There was no trend between years for the $\mathrm{P}$ or $\mathrm{N}$ forms across the PRB.

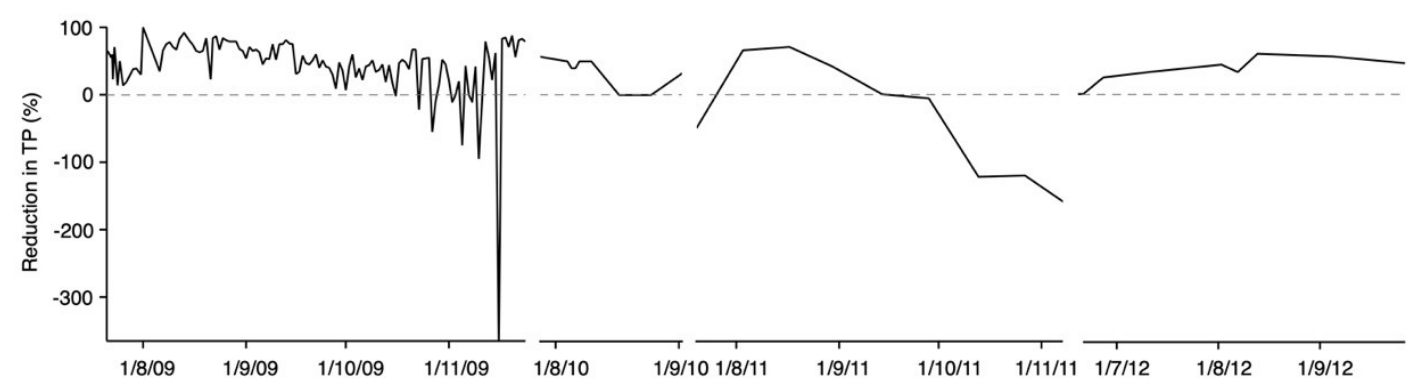

Figure 4. The reduction in TP concentration from above and below the PRB. Above the dashed line is a reduction in TP concentration

\subsection{Physio-chemical Parameters}

Concentrations of total suspended solids (TSS) at the inlet were initially very high following disturbance during pond construction. In 2009 the TSS concentration fell between the pond inlet (Figure 1 a) and the monitoring point above the PRB (Figure $1 \mathrm{~b}$ ) by $61 \%$ (131 to $51.1 \mathrm{mg} \mathrm{L}^{-1}$ ) and from 2010 to 2012 by $-46 \%$ (6.85 to $12.0 \mathrm{mg} \mathrm{L}^{-1}$ ) (Figure 3 e). The TSS concentration fell across the PRB by 56\% (44.3 to $\left.19.2 \mathrm{mg} \mathrm{L}^{-1}\right)$ between 2009 and 2012 (Figure $3 \mathrm{e}$ ). The mean $\mathrm{pH}$ (not shown) increased across the PRB by 0.21 units $(p<0.001$ ) from 7.42 to 7.63 but this fell to $7.39(p<0.001$ compared with below the PRB) at the outlet of the pond and was $7.44(p<0.01$ compared with below the PRB) in the Mayfield drain from 2009 to 2012. The mean EC (not shown) increased across the PRB from 48 to $54 \mathrm{mS} \mathrm{m}^{-1}(p<0.001)$ and remained unchanged at the outlet of the pond and increased to $127 \mathrm{mS} \mathrm{m}^{-1}(p<0.01$ compared with below the PRB) in the Mayfield drain. There was no seasonal or annual trend in $\mathrm{pH}$ or EC across the PRB. The DO was lower in the PRB compared with other sampling points even when tested at the surface and the bottom of the water column (Figure 5 a).

\subsection{Analytes of Concern}

The concentration of most elements in the upstream pond was low relative to guidelines and background levels. Al and $\mathrm{U}$ were the exceptions (Table 2) with the concentration of Al entering the pond being above the guideline values and also increasing during the transit through the pond. The $\mathrm{U}$ concentration increased from the inlet to the pond to immediately above the PRB by $300 \%$ ( 0.0001 to $\left.0.0004 \mathrm{mg} \mathrm{L}^{-1}\right)$. The $\mathrm{U}$ concentration increased from immediately upstream of the PRB to immediately below the PRB (2009 to 2012) by $175 \%$ (0.0004 to $0.0011 \mathrm{mg}$ $\left.\mathrm{L}^{-1}\right)$ and the increase was greatest in 2010 at $650 \%\left(0.0002\right.$ to $\left.0.0015 \mathrm{mg} \mathrm{L}^{-1}\right)$ (Figure $3 \mathrm{f}$ ).

Elements increased $(p<0.05)$ by the PRB were arsenic*, cobalt*, EC, fluoride* (lower than the inlet concentration), manganese*, molybdenum*, selenium*, uranium (U), and vanadium* (V) (Table 2) (*close to detection limits and/or means below guidelines).

Uranium was the only element that increased in concentration across the PRB and was higher than the relevant guidelines $(p<0.0001)$ (Table 2).

Elements decreased $(p<0.05)$ by the passage through the PRB were aluminium (Al), ammonium-N, FRP, iron* (Fe) (generally decreased except a slight increase during the low flows and rising temperature in spring), lead*, nitrate N, TSS, TN, and TP (*close to detection limits and/or means below guidelines).

Elements that were generally unaffected $(p<0.05)$ by the PRB or at very low concentrations were boron*, beryllium*, cadmium*, copper*, chromium (VI)*, chromium (total)*, mercury*, nickel*, silver*, thorium*, tin*, and zinc* (*close to detection limits and/or means below guidelines). 
There was a positive linear relationship between the concentration of Fe and $\mathrm{P}$ in water sampled below the PRB (Figure $5 \mathrm{~b}$ ). There was a negative, non-linear relationship between $\mathrm{Fe}$ and $\mathrm{U}$ in the water sampled below the PRB (Figure $5 \mathrm{c}$ ).

Table 2. Mean Concentration of Elements $\left(\mathrm{mg} \mathrm{L}^{-1}\right)$ at each Sampling Point in the Pond and Downstream Compared to ANZECC and ARMCANZ (2000) Guidelines for Drinking Water and ANZECC and ARMCANZ (2000) 80\%, 95\% Fresh Water Investigation Trigger Levels of Protection (ND = not detected in any sample). Samples below Detection Limits Assigned Half the Detection Limit. Cells shaded = guidelines were exceeded; underlining $=$ significant change $(\mathrm{p}<0.05)$ across the PRB; bold text $=$ an increase. Trend $\mathrm{p}: *<0.05 ; * *<0.01$;

\begin{tabular}{|c|c|c|c|c|c|c|c|c|c|c|}
\hline Element & Inlet & $\begin{array}{l}\text { Above } \\
\text { PRB }\end{array}$ & $\begin{array}{c}\text { Below } \\
\text { PRB }\end{array}$ & Outlet & $\begin{array}{l}\text { Mayfield } \\
\text { drain }\end{array}$ & $\begin{array}{c}\text { Detecti } \\
\text { on } \\
\text { limit }\end{array}$ & $\begin{array}{c}\text { Drinking } \\
\text { water } \\
\text { guideline }\end{array}$ & $\begin{array}{c}\text { Fresh water } \\
\text { guideline } \\
95 \% \\
\text { protection }\end{array}$ & $\begin{array}{c}\text { Fresh } \\
\text { water } \\
\text { guideline } \\
80 \% \\
\text { protection }\end{array}$ & $\begin{array}{c}\text { Trend } \\
\text { across } \\
\text { PRB }\end{array}$ \\
\hline $\mathrm{Ag}$ & ND & ND & ND & ND & ND & 0.0001 & 0.1 & 0.00005 & 0.0002 & \\
\hline $\mathrm{Al}$ & 0.36 & $\underline{0.59}$ & $\underline{0.03}$ & 0.41 & 0.73 & 0.005 & 0.2 & 0.055 & 0.15 & Decrease* \\
\hline As & ND & $\underline{0.00053}$ & $\underline{0.00095}$ & 0.0011 & 0.0005 & 0.001 & 0.007 & 0.024 & 0.36 & Increase ${ }^{* *}$ \\
\hline B & 0.01 & 0.015 & 0.016 & 0.011 & 0.01 & 0.02 & 0.3 & 0.37 & 1.3 & \\
\hline $\mathrm{Be}$ & ND & 0.00007 & ND & ND & ND & 0.0000 & & 0.00013 & & \\
\hline $\mathrm{Cd}$ & 0.000 & 0.0001 & 0.0001 & 0.0001 & 0.0001 & 0.0001 & 0.002 & 0.0002 & 0.0008 & \\
\hline $\mathrm{Co}$ & 0.000 & $\underline{0.0001}$ & $\underline{0.0002}$ & 0.0002 & 0.0004 & 0.0001 & & & & Increase* \\
\hline $\mathrm{Cr}$ & 0.000 & 0.0006 & 0.0007 & 0.0007 & 0.0006 & 0.0005 & 0.05 & 0.001 & 0.04 & \\
\hline $\mathrm{Cr}$ (IV) & ND & ND & ND & ND & ND & 0.0005 & & & & \\
\hline $\mathrm{Cu}$ & 0.004 & 0.0023 & 0.0012 & 0.0028 & 0.0015 & 0.0001 & 2 & 0.0014 & 0.0025 & \\
\hline $\mathrm{F}$ & 0.33 & $\underline{0.09}$ & $\underline{0.32}$ & 0.29 & 0.15 & 0.05 & 1.5 & & & Increase ${ }^{* *}$ \\
\hline $\mathrm{Fe}$ & 0.56 & $\underline{0.415}$ & $\underline{0.205}$ & 0.27 & 0.96 & 0.005 & 0.3 & & & Decrease* \\
\hline $\mathrm{Hg}$ & ND & ND & ND & ND & ND & 0.0000 & 0.001 & 0.0006 & 0.0054 & ND \\
\hline Mo & 0.001 & $\underline{0.0006}$ & $\underline{0.0031}$ & 0.0021 & 0.009 & 0.001 & 0.05 & 0.034 & & Increase ${ }^{* *}$ \\
\hline $\mathrm{Mn}$ & 0.041 & $\underline{0.0037}$ & $\underline{0.0067}$ & 0.0094 & 0.024 & 0.001 & 0.5 & 1.9 & 3.6 & Increase* \\
\hline $\mathrm{Ni}$ & 0.002 & 0.006 & 0.001 & 0.008 & 0.001 & 0.001 & 0.02 & 0.011 & 0.017 & \\
\hline $\mathrm{Pb}$ & 0.000 & $\underline{0.0003}$ & $\underline{0.0002}$ & 0.0002 & 0.0004 & 0.0001 & 0.01 & 0.0034 & 0.0094 & Decrease* \\
\hline $\mathrm{Se}$ & 0.001 & $\underline{\text { ND }}$ & $\underline{0.001}$ & 0.001 & ND & 0.001 & 0.01 & 0.011 & 0.034 & Increase ${ }^{* *}$ \\
\hline $\mathrm{Sn}$ & ND & ND & ND & ND & ND & 0.0001 & & 0.003 & & \\
\hline Th & 0.000 & 0.0002 & 0.0003 & 0.0003 & 0.0003 & 0.0001 & & & & \\
\hline V & 0.001 & $\underline{0.0014}$ & $\underline{0.0038}$ & 0.0033 & 0.0022 & 0.0001 & & 0.006 & & Increase ${ }^{* *}$ \\
\hline $\mathrm{U}$ & 0.000 & 0.0004 & 0.0011 & 0.0008 & 0.0004 & 0.0001 & 0.02 & 0.0005 & & Increase ${ }^{* *}$ \\
\hline $\mathrm{Zn}$ & 0.027 & 0.006 & 0.006 & 0.006 & 0.006 & 0.001 & 3 & 0.008 & 0.031 & \\
\hline
\end{tabular}

\subsection{Radiological Assessment}

Table 3. Radiological Assessment of Water Samples from above and below the PRB

\begin{tabular}{llccc}
\hline Date & Location & Alpha $\left(\mathrm{mBq} \mathrm{L}^{-1}\right)$ & Beta $\left(\mathrm{mBq} \mathrm{L}^{-1}\right)$ & $\mathrm{K}\left(\mathrm{mg} \mathrm{L}^{-1}\right)$ \\
\hline 20-24 Jul 2009 & Above PRB & $<\mathrm{MDL}$ & $<\mathrm{MDL}$ & 5.0 \\
20-24 Jul 2009 & Below PRB & $24 \pm 4$ & $17 \pm 2$ & 4.5 \\
5 Nov 2009 & Above PRB & $10.6 \pm 2.6$ & $101 \pm 13$ & 11 \\
5 Nov 2009 & Below PRB & $<$ MDL & $37.3 \pm 5.1$ & 11 \\
\hline
\end{tabular}

The results for Gross Alpha/Beta analyses (to 95\%, 2SD confidence level). The gross Beta results were corrected for potassium 40 concentrations. MDL (maximum detectable limit) Alpha $5 \mathrm{mBq} \mathrm{L}^{-1}$, Beta $10 \mathrm{mBq} \mathrm{L}^{-1}$.

The alpha and beta emissions were low and close to the drinking water guideline of $0.5 \mathrm{~Bq} \mathrm{~mL}^{-1}$ (ANZECC and ARMCANZ, 2000) (Table 3). Emissions increased across the PRB on the first sampling and decreased on the 
second sampling.
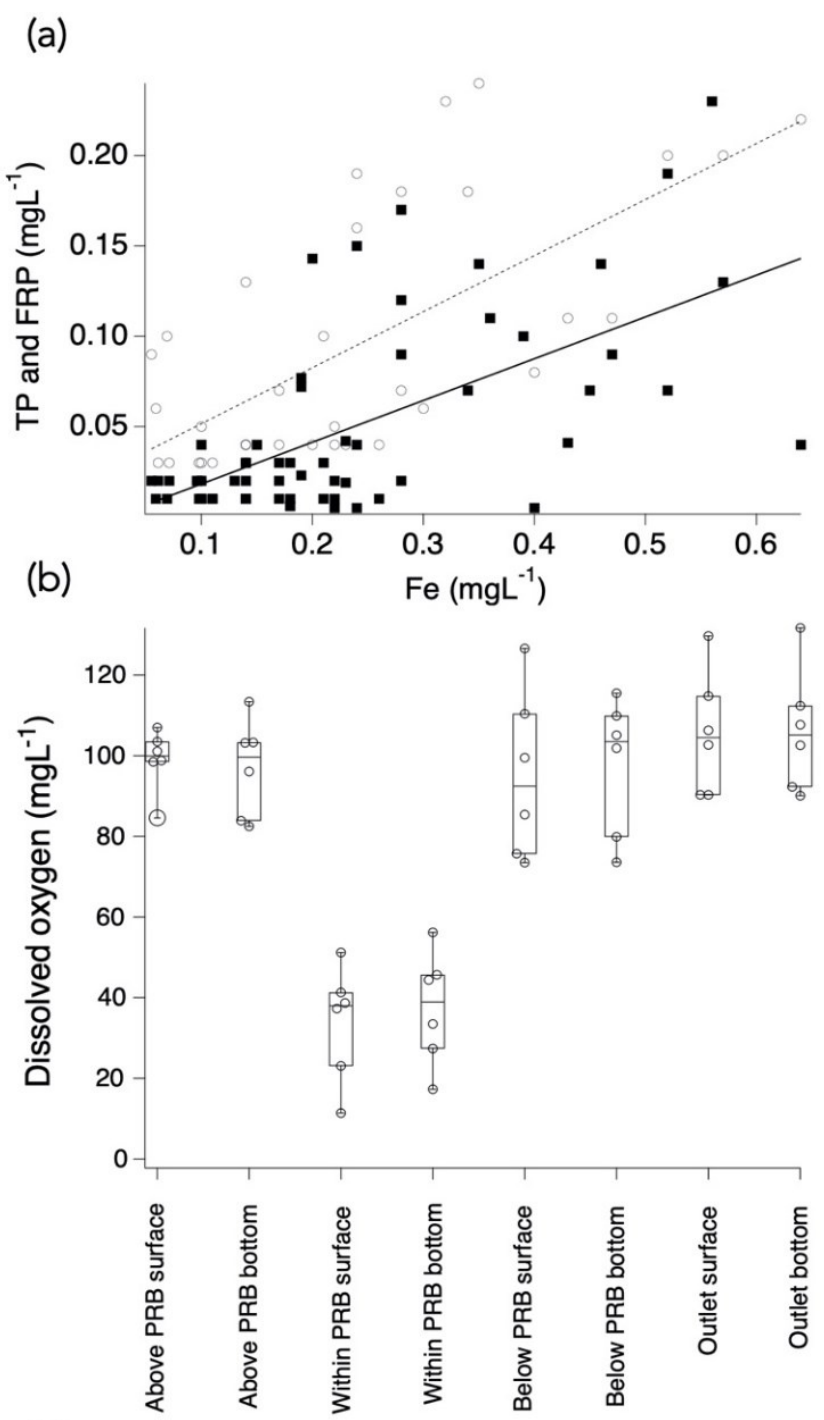

(c)

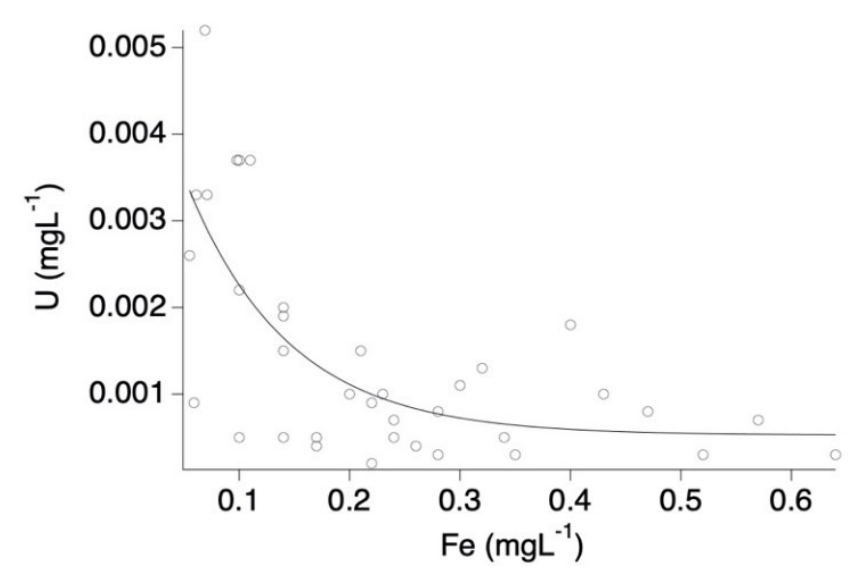

Figure 5. (a) DO at sampling sites in the pond, (b) The relationship between the concentration of Fe and TP (open circles, dashed line); and Fe and FRP (squares, solid line) sampled immediately downstream of the PRB, TP $[\mathrm{y}=$ $0.3100 \pm 0.057 \mathrm{x}+0.0206 \pm 0.0159\left( \pm 1\right.$ Std Dev) $\left.\mathrm{r}^{2}=0.46\right] ;$ FRP $[\mathrm{y}=-0.0048 \pm 0.0107 \mathrm{x}+0.231 \pm 0.038( \pm 1$ Std Dev $)$ $\left.\mathrm{r}^{2}=0.39\right]$ and (c) the relationship between the concentration of Fe and $\mathrm{U}$ sampled immediately downstream of the PRB, $y=0.000527 \pm 0.000348+0.005132 \pm 0.00166 \exp (-10.9 \pm 4.9 x)( \pm 1$ std dev $) r^{2}=0.43$. 


\section{Discussion}

\subsection{Flow and the PRB}

Groundwater ingress through the base of the pond occurred before surface runoff entered the pond. This resulted in flow monitoring being abandoned after the first year. These data do not provide information on the volume of water that flowed through the pond because a proportion of the total flow at the pond outlet was derived from rising groundwater underneath the pond. However, they do provide an upper limit to the flow through the PRB of approximately $500 \mathrm{~m}^{3}$ day $^{-1}$ over the $26 \mathrm{~m}^{2}$ of PRB, which would be a maximum hydraulic conductivity of 0.00022 $\mathrm{m} \mathrm{sec}^{-1}$ or about $19 \mathrm{~m} \mathrm{day}^{-1}$. The actual flow through the pond could not be determined without an estimate of the groundwater flow and thus flow monitoring ceased after 2009.

Issues of limited permeability (either through clogging from the water or from segregation of the media) have previously been encountered in WA. In one case, clogging of Bassendean sand using river water occurred at the surface of the media. This was believed to be caused by suspended solids or algal films filling the interstitial spaces in the media voids (Cameron \& Ho, 1981). Cameron and Ho (1981) observed a 93\% reduction in hydraulic conductivity ( 6.3 to $0.42 \mathrm{~m} \mathrm{day}^{-1}$ ) in 22 days of passive infiltration on Bassendean sand, which is a large component of the PRB used here. The coarse pores of the sand may have been clogged by the finer bauxite residue as well as particulates travelling in the water where the PRB was found to retain about half of the TSS. In a study of PRBs using a mineral sands by-product as $25 \%$ of a mixture with coarse river sand with both active and passive infiltration of river water, the hydraulic conductivity commenced at $8.6 \mathrm{~m}_{\text {day }}{ }^{-1}$ but rapidly decreased. This decrease was attributed to particle segregation and migration of fine particles blocking the pores of the media (ChemCentre, 2012). The selection of coarse sand and coarse limestone was not sufficient to avoid reducing the hydraulic conductivity of the PRB. An alternative for investigation is the selection of a coarser P retentive media, which has less fines to cause blockage than the fine bauxite residue. In the bauxite refining process, a separate fraction of bauxite residue is produced that has a particle size similar to fine sand which may improve permeability, or alternatively granulating bauxite residue may provide a solution.

\subsection{Phosphorus and Nitrogen}

The reduction in $\mathrm{P}$ and $\mathrm{N}$ concentration in the upstream pond was high (TP 85\% and FRP 96\%; TN $66 \%$ and $89 \%$ $\mathrm{NO}_{3}-\mathrm{N}$ ). This reduction was likely mainly by sorption onto the bed of the pond (in the case of $\mathrm{P}$ ), volatilization (in the case of $\mathrm{N}$ ), dilution from groundwater, incorporation into biofilms or algae and to a lesser extent by settling of particulate $\mathrm{P}$ as shown by the high proportion of FRP over the monitoring period $(79 \%)$. The reduction in $\mathrm{P}$ in the upstream pond is consistent with $\mathrm{EPC}_{0}$ dynamics (Froelich, 1988; Taylor \& Kunishi, 1971), particularly since the pond was freshly constructed and would therefore provide substrate surfaces that had very little previous exposure to $\mathrm{P}$, maximizing the potential for $\mathrm{P}$ retention. Exposure of subsoil and increased $\mathrm{P}$ retention of surfaces exposed to runoff has been shown to increase $P$ retention in the sediment of drainage systems and in the soil of irrigation bays (Clarendon et al., 2019; Nash et al., 2007; R. Summers et al., 2014) and the exploitation of this mechanism has potential to manage $\mathrm{P}$ concentrations in drainage water.

Some retention of $\mathrm{P}$ and $\mathrm{N}$ due to settling of particulates is likely, however this effect may be limited because TSS concentrations in inflow and through the pond did not mirror P and N concentrations. TSS reduction was $61 \%$ initially in 2009 and $46 \%$ in 2010 to 2012, whilst $\mathrm{P}$ and $\mathrm{N}$ concentrations were always much higher in inflow, and otherwise consistent through the pond. No plants grew in the pond that could contribute to $\mathrm{P}$ or $\mathrm{N}$ removal by plant uptake and their removal in the upstream pond lasted the 4 years of monitoring without any appreciable decline. The lack of plant nutrient uptake and limited settling suggests $\mathrm{P}$ retention by sorption, and $\mathrm{N}$ loss via volatilization as primary mechanisms in the upstream pond combined with retention in biofilms. Oxygen levels even at the deepest point in the pond were greater than in the PRB, thus reducing the chance of anaerobic conditions developing with the associated release of $\mathrm{P}$.

Studies of artificial wetlands in similar sandy soils in WA have found that sediments provided a significantly greater pool of nutrients than wetland vegetation, with these sediments assimilating $\mathrm{P}$ and $\mathrm{N}$ from surface water and groundwater sources (Adyel, Ocampo, Tareque, Oldham, \& Hipsey, 2015; Ruibal-Conti, Ocampo, Adyel, Hipsey, \& Oldham, 2015). However, artificial wetlands may also become a source of $\mathrm{P}$ with the release of $\mathrm{P}$ from sediments (Palmer-Felgate et al., 2011). While the P retentive effect of the upstream pond was not anticipated, it is possible to monitor the initial and remaining capacity of sediment to retain $P$ relative to the influent concentration using the $\mathrm{EPC}_{0}$ (Froelich, 1988; Lucci et al., 2010; Taylor \& Kunishi, 1971). This variable capacity to sorb and desorb $\mathrm{P}$ dependant upon the influent concentrations has been observed in fluvarium studies and can be manipulated by changes to characteristics of the retentive media (Clarendon et al., 2019). The capacity of the sediment to retain $\mathrm{P}$ is limited (Barrow, 2021) and the $\mathrm{EPC}_{0}$ will decline with exposure to $\mathrm{P}$ concentrations higher 
than the $\mathrm{EPC}_{0}$. If there is seasonal variation in the influent $\mathrm{P}$ concentration, it is possible to use the $\mathrm{EPC}_{0}$ to predict the proportion of the year that the sediment will be a sink for $\mathrm{P}$ or a source.

$\mathrm{P}$ removal by sediments on the bed of the pond has also been supported by evidence of $\mathrm{P}$ removal from FRP by sediments in the drainage systems of similar sandy catchments near the study area and on the south coast of WA (Clarendon et al., 2019; McKergow, Prosser, Weaver, Grayson, \& Reed, 2006; McKergow, Weaver, Prosser, Grayson, \& Reed, 2003; R. Summers et al., 2014). Where the sediments remain undisturbed in these studies, P removal was eventually overcome by $\mathrm{P}$ saturation of the surface layer of sediment. If sediment becomes saturated with $\mathrm{P}$, there may be potential to regenerate this P-retention capacity by exposing more layers below the sediment surface or by applying more retentive material onto the sediment.

There is a case for exploring a range and combination of retention mechanisms in constructed wetlands where the impact of the various sinks in a wetland is likely to be affected by time and exposure to the water column. Vegetation may remove $\mathrm{P}$ in the short term however, it may act as a barrier to interaction with sediment. In a 2-year study of a series of well-vegetated constructed ponds lined with bauxite residue and sand, most of the $\mathrm{P}$ was retained in the vegetation and little in the sediment and the authors suggested that plant uptake may decline as the vegetation matures and that biofilms may take over P removal (Lund, Lavery, \& Froend, 2001). Biofilms may have been operating to retain $\mathrm{P}$ in the upstream pond studied here.

Although ponds increase residence time for dissolved $\mathrm{P}$ to interact with sediments and settle particulate $\mathrm{P}$, capacity can be overwhelmed in high-discharge events, which contain the bulk of the P load (Reinhardt et al., 2005). The shallow pond upstream of the PRB here showed the capacity of the bed of the pond to retain P and highlights the opportunity to extend the interaction of drainage water along the length of the drainage path to retain $\mathrm{P}$ under aerobic conditions. Constructed wetlands have a role in improving water quality, but the strategy depends on effective design (Braid, 1995) and many variables affect the longevity.

The PRB effectively reduced the concentration of TP by $53 \%$ and FRP by $55 \%$ but at low concentrations (TP 0.193 and FRP $0.087 \mathrm{mg} \mathrm{L}^{-1}$ ), and TN by $37 \%$ and $\mathrm{NO}_{3}-\mathrm{N}$ by $46 \%$ which would be useful for polishing water already treated by other management practices. We were unable to test the effectiveness of the PRB to remove high concentrations of $\mathrm{P}$ and $\mathrm{N}$ because the upstream pond was so effective at removing $\mathrm{P}$. It is likely that $\mathrm{P}$ reduction by the PRB was predominantly due to the bauxite residue. The limestone used here was very coarse, and previous studies have shown that finer limestone $(<0.9 \mathrm{~mm}$ compared with $>2 \mathrm{~mm}$ used here) was ineffective in retaining $\mathrm{P}$ at low P concentrations (Johansson, 1999). This is supported by the very slight increase in $\mathrm{pH}$ of 0.21 units to 7.63 across the PRB indicating limited dissolution of the coarse limestone or alkaline components of the bauxite residue. Further confirmation of this has been $\mathrm{pH}$ dependent leaching tests using bauxite residue combined with the same native sand which showed that the retention of $\mathrm{P}$ was an attribute of the bauxite residue and not an artefact of the pH change (Carter et al., 2009).

$\mathrm{N}$ removal was not the primary purpose of the pond and filter system, however, the passage through the PRB enabled further $\mathrm{N}$ removal which may have been a continuation of the processes that occurred in the upstream pond in combination with potential anaerobic $\mathrm{N}$ removal from the $\mathrm{NO}_{3}-\mathrm{N}$ pool perhaps fueled by tannins as a carbon source.

\subsection{Analytes of Concern}

Most elements generally dropped in concentration between 2009 and 2011. The concentration of all elements that were discharged from the pond at the weir were at similar concentrations to that above the PRB and to those found in the nearby Mayfield drain. Groundwater ingress may also act to dilute the concentration of elements that may otherwise have increased following passage of water through the PRB before discharge over the weir. The EC across the weir increased by only $11 \%$ and could still be regarded as fresh water. This slight increase was steady from 2009 to 2012 suggesting elements were continuously being discharged from the PRB media. The salinity was still low in comparison with the nearby Mayfield drain which was draining agricultural land.

Most of the increases in concentration of elements of concern were slight or were very close to the commonly found background levels measured nearby (Table 2). $\mathrm{U}$ and $\mathrm{V}$ concentrations increased across the PRB and then dropped to near background levels by the time they left the downstream pond over the weir. The concentration of V was well below the ANZECC and ARMCANZ (2000) 95\% environmental concern level. The only element of concern was U which increased above the ANZECC and ARMCANZ (2000) guideline. However, the concentration of $U$ in the Mayfield drain could be considered a background measure since it drains a large area of agricultural land. Concentrations of $U$ in the Mayfield drain were also high and exceeded the ANZECC and ARMCANZ (2000) guideline on 17 out of 43 occasions. The PRB media was predominantly crushed limestone and dissolved carbonates in close proximity to the bauxite residue may have promoted U solubility, forming highly 
mobile anionic species (Lee, Elless, \& Hoffman, 1993). Although the concentration of $U$ in the water draining from the PRB was relatively low, it exceeded the conservative ANZECC and ARMCANZ (2000) water quality guideline and future designs should evaluate the impact of limestone as a component of the media.

Investigation of a PRB media using a by-product from mineral sand processing found very similar results with the release of low levels of soluble $\mathrm{U}(>0.003 \mathrm{mg} / \mathrm{L})$, which the authors related to increases in $\mathrm{U}$ concentration during periods of low flow in their PRB (ChemCentre, 2012). Low flow through the PRB could also have been responsible for the release of $U$ through the PRB here. The authors (ChemCentre, 2012) stated that there are no high reliability trigger values for $U$ in the ANZECC and ARMCANZ (2000) guidelines for freshwater aquatic ecosystems and that the low reliability value of $0.0005 \mathrm{mg} \mathrm{L}^{-1}$ was calculated using a conservative factor of 20 , based on limited chronic toxicity data. They believed that while the observed concentrations exceed the trigger value, these concentrations are unlikely to result in significant toxicity issues. The concentration of $U$ considered safe by ChemCentre (2012) were above those we measured at the exit of the downstream pond.

$\mathrm{Fe}$ and $\mathrm{Al}$ concentrations were generally decreased by the PRB but all samples from the pond and surrounding areas were above the ANZECC and ARMCANZ (2000) 95\% environmental concern levels, indicating that these are commonly occurring contaminants in the area. Al concentrations in the surrounding Peel-Harvey catchment are commonly high and have been shown to exceed freshwater guidelines. The $\mathrm{Al}$ is closely associated with tannins in the water which are likely to be protective of freshwater organisms (R. Summers \& Pech, 1997). The reduction in $\mathrm{Al}$ concentration across the PRB may have been partly due to the retention of the tannins carrying the $\mathrm{Al}$, either through attachment to the bauxite residue particles or precipitation caused by the limestone. Supporting this is the observation that dissolved organic carbon leaching was reduced by addition of bauxite residue to the same soil used here and $\mathrm{Al}$ was predicted to be associated with humic and fulvic acids at or near neutral $\mathrm{pH}$ (Carter et al., 2009).

The impact of anoxic, reducing conditions causing a minor P release is suggested by the positive relationship between Fe and P, and low DO inside the PRB. The low DO may be causing Fe oxides to be reduced in the PRB and have contributed to the release of $\mathrm{P}$ previously attached to the Fe oxides. Although not measured, tannins and other organic materials were observed in the water and could be a potential food source for microbial respiration and a reduction in TSS (56\%) across the PRB may have resulted in a component of organic removal likely in the TSS. The native soil is also likely to be a source of organic matter in the PRB.

This anoxic driven mechanism would be restricted to the PRB, as shown by the relatively high DO at all the sampling sites and would have created aerobic rather than anoxic conditions. This relationship with Fe did not contribute to $\mathrm{U}$ dissolution mentioned above, but rather was a negative relationship where the $\mathrm{U}$ species comes into solution under oxidative conditions and precipitates readily under reductive conditions (Appelo \& Postma, 2004).

Measuring the concentration of radioisotopes, especially those of concern such as the radioactive daughter products of decay of elements such as $U$ and Th can be problematic because even at low concentrations, they are potentially biologically hazardous. Measuring their emissions is more sensitive and is specific to the potential threat. The alpha and beta emissions from both above and below the PRB on both sampling occasions were very low and less than the Australian drinking water guideline of $0.5 \mathrm{~Bq} \mathrm{~mL}^{-1}$ (ANZECC and ARMCANZ, 2000); these emissions were slightly increased by the PRB initially and later slightly decreased by the PRB. The low alpha and beta emissions of the water above and below the PRB shows it posed little or no threat from the discharge of radioisotopes into the water during the monitoring at the commencement of the study.

\section{Conclusions}

Although not anticipated, $\mathrm{P}$ concentrations decreased substantially in the upstream pond, possibly due to sorption, sedimentation, or dilution. With P sorption onto sediments being measured as effectively removing $\mathrm{P}$ here and in a number of studies, the base of wetlands or drains may be a better target for nutrient-retentive media than a PRB and worth exploring, considering the very high removal rate of $\mathrm{P}$ and $\mathrm{N}$ (and some other elements). This is especially so where the depth of the water and flow conditions enable the water to be aerobic and interact with the sediment.

The hydraulic conductivity of the PRB was too low to prevent overtopping and this may have been due to clogging of the filter media which has been observed in other studies. It may be necessary to consider other media which is graded to avoid particle segregation and much coarser reactive media may improve flow.

The PRB was very effective at removing P at low concentrations. The full performance of the PRB could not be explored due to groundwater ingress confounding the results and also the upstream pond removing most of the $\mathrm{P}$ before it reached the PRB. Anaerobic conditions in the PRB and restrictions to flow are undesirable features and makes the use of PRBs in highly seasonal rainfall patterns problematic. The quality of the water draining from the 
pond was low in contaminants and was similar to that in surrounding waters.

Future PRB design needs to consider the impacts of periods of anaerobic conditions and align drainage to avoid interception by groundwater with periods of stagnant ponding.

\section{Acknowledgments}

Contributions to the development of the project were made by former Department of Primary Industries and Regional Development employees: Nardia Keipert, Martin Clarke, Fred Robinson, and Simon Vivian.

Technical contributions were made by Eddy Wajon (formerly Conservation Council Western Australia), Shelly Attiwell (Alcoa World Alumina), and David Cooling (formerly Alcoa World Alumina).

The PRB was a Storm-Max stormwater treatment system donated and constructed by the Wallis Group, Hamilton Hill, Western Australia.

Authors have previously received funding from Alcoa World Alumina for studies into the use of bauxite residue for soil amendment in agricultural applications. Residual funds were released for chemical analysis in this project. The funders had no role in the design of the study; in the collection, analyses, or interpretation of data; in the writing of the manuscript, or in the decision to publish the results.

\section{References}

Adyel, T. M., Ocampo, C., Tareque, H., Oldham, C., \& Hipsey, M. (2015). Performance assessment of Wharf Street Constructed Wetland 2009-2014. Retrieved from https://www.researchgate.net/profile/Tanveer_Adyel/publication/291697380_Performance_assessment_of_ Wharf_Street_Constructed_Wetland_2009-2014/links/56a5223808aef91c8c14d34c/Performance-assessmen t-of-Wharf-Street-Constructed-Wetland-2009-2014.pdf

Allen, D. G., \& Jeffery, R. C. (1990). Methods for analysis of phosphorus in Western Australian soils- Report of investigation no: 37. Agricultural Chemistry Laboratory, Chemistry Centre of Western Australia.

ANZECC and ARMCANZ. (2000). Australian and New Zealand Guidelines for Fresh and Marine Water Quality. Retrieved from https://www.waterquality.gov.au/anz-guidelines/resources/previous-guidelines/anzecc-armcanz-2000

Appelo, C. A. J., \& Postma, D. (2004). Geochemistry, groundwater and pollution. CRC press.

Barron, O., Donn, M., Pollock, D., \& Johnstone, C. (2010). Determining the effectiveness of best management practices to reduce nutrient flows in urban drains managed by the Water Corporation. Water for a Healthy Country National Research Flagship Report. Retrieved from https://publications.csiro.au/rpr/download?pid=csiro:EP104807\&dsid=DS4

Barrow, N. (2021). Comparing two theories about the nature of soil phosphate. European Journal of Soil Science, $72(2), 679-685$.

Bolland, M., Gilkes, R., Brennan, R., \& Allen, D. (1996). Comparison of seven phosphorus sorption indices. Soil Research, 34(1), 81-89. https://doi.org/10.1071/sr9960081

Bos, M. G. (1989). Discharge Measurement Structures. PO Box 45, 6700 AA Wageningen, The Netherlands: International Institute for Land Reclamation and Improvement/ILRI, PO Box 45, 6700 AA Wageningen, The Netherlands.

Braid, A. (1995). Constructed Wetland Design Criteria: A study of their role in contaminant removal from urban stormwater runoff. $\quad$ Retrieved from http://ro.ecu.edu.au/cgi/viewcontent.cgi?article=1284\&context=theses_hons

Burkitt, L., Moody, P., Gourley, C., \& Hannah, M. (2002). A simple phosphorus buffering index for Australian soils. Australian Journal of Soil Research, 40, 497-513. https://doi.org/10.1071/sr01050

Cameron, I., \& Ho, G. (1981). Clogging mechanisms in groundwater recharge using river water. Australasian Water and Wastewater Association Ninth Federal Convention Perth, 6-12. Retrieved from https://researchrepository.murdoch.edu.au/id/eprint/22238/1/clogging_mechanisms_in_groundwater_rechar ge.pdf

Carter, C., Van der Sloot, H., \& Cooling, D. (2009). pH-dependent extraction of soil and soil amendments to understand the factors controlling element mobility. European Journal of Soil Science, 60(4), 622-637. https://doi.org/10.1111/j.1365-2389.2009.01139.x

ChemCentre. (2012). Nutrient filter pilot trial Ellen Brook Western Australia. Retrieved from Perth, Western 
$\begin{array}{llll}\text { Australia. } & \text { Project } & \text { T23601. } & \text { Retrieved }\end{array}$ https:/consultation.epa.wa.gov.au/seven-day-comment-on-referrals/a569617/supporting_documents/Nutrie nt\%20Filter\%20Pilot\%20Trial\%20Mar\%202012_ChemCentre\%20Report.pdf

Clarendon, S. D. V., Weaver, D. M., Davies, P. M., \& Coles, N. A. (2019). The influence of particle size and mineralogy on both phosphorus retention and release by streambed sediments. Journal of Soils and Sediments, 19(5), 2624-2633. https://doi.org/10.1007/s11368-019-02267-w

Drizo, A., Frost, C., Grace, J., \& Smith, K. (1999). Physico-chemical screening of phosphate-removing substrates for use in constructed wetland systems. Water Research, 33(17), 3595-3602. https://doi.org/10.1016/s0043-1354(99)00082-2

Eaton, A. D., Clesceri, L. S., Rice, E. W., Greenberg, A. E., \& Franson, M. A. H. (2005). Standard methods for the examination of water and wastewater. American public health association.

Froelich, P. N. (1988). Kinetic control of dissolved phosphate in natural rivers and estuaries A primer on the phosphate buffer mechanism. Limnology and Oceanography, 33(4), 649-668. https://doi.org/10.4319/1o.1988.33.4part2.0649

Gourley, C., \& Weaver, D. (2012). Nutrient surpluses in Australian grazing systems management practices, policy approaches, and difficult choices to improve water quality. Crop and Pasture Science, 63(9), 805-818. https://doi.org/10.1071/cp12154

Hodgkin, E., \& Hamilton, B. (1993). Fertilizers and eutrophication in southwestern Australia setting the scene. Fertiliser Research, 36(2), 95-103. https://doi.org/10.1007/bf00747579

Johansson, L. (1999). Industrial by-products and natural substrata as phosphorus sorbents. Environmental Technology, 20(3), 309-316. https://doi.org/10.1080/09593332008616822

Lee, S., Elless, M., \& Hoffman, F. (1993). Solubility measurement of uranium in uranium-contaminated soils. Retrieved from https://www.osti.gov/servlets/purl/10115558

Lucci, G. M., McDowell, R. W., \& Condron, L. M. (2010). Evaluation of base solutions to determine equilibrium phosphorus concentrations (EPC0) in stream sediments. International Agrophysics, 24(1), 157-163.

Lund, M., Lavery, P., \& Froend, R. (2001). Removing filterable reactive phosphorus from highly coloured stormwater using constructed wetlands. Water Science and Technology, 44(11-12), 85-92. https://doi.org/10.2166/wst.2001.0813

McComb, A., \& Humphries, R. (1992). Loss of Nutrients from Catchments and Their Ecological Impacts in the Peel-Harvey Estuarine System, Western Australia. Estuaries, 15(4), 529-537. https://doi.org/10.2307/1352395

McKergow, L., Prosser, I., Weaver, D., Grayson, R., \& Reed, A. (2006). Performance of grass and eucalyptus riparian buffers in a pasture catchment, Western Australia, part 2 water quality. Hydrological Processes, 20(11), 2327-2346. https://doi.org/10.1002/hyp.6054

McKergow, L., Weaver, D., Prosser, I., Grayson, R., \& Reed, A. (2003). Before and after riparian management sediment and nutrient exports from a small agricultural catchment, Western Australia. Journal of Hydrology, 270(3-4), 253-272. https://doi.org/10.1016/s0022-1694(02)00286-x

Mcpharlin, I., Jeffery, R., Toussaint, L., \& Cooper, M. (1994). Phosphorus, nitrogen, and radionuclide retention and leaching from a joel sand amended with red mud/gypsum. Communications in Soil Science and Plant Analysis, 25(17), 2925-2944. https://doi.org/10.1080/00103629409369235

Nash, D., Webb, B., Hannah, M., Adeloju, S., Toifl, M., Barlow, K., . . Porter, N. (2007). Changes in nitrogen and phosphorus concentrations in soil, soil water and surface run-off following grading of irrigation bays used for intensive grazing. Soil Use and Management, 23(4), 374-383. https://doi.org/10.1111/j.1475-2743.2007.00100.x

Nelson, P. (2003). Index to EPA test methods. United States Environmental Protection Agency, Region I.

Palmer-Felgate, E. J., Bowes, M. J., Stratford, C., Neal, C., \& MacKenzie, S. (2011). Phosphorus release from sediments in a treatment wetland: Contrast between DET and EPC0 methodologies. Ecological Engineering, 37(6), 826-832. https://doi.org/10.1016/j.ecoleng.2010.12.024

Reinhardt, M., Gachter, R., Wehrli, B., \& Muller, B. (2005). Phosphorus retention in small constructed wetlands treating agricultural drainage water. Journal of Environmental Quality, 34(4), 1251-1259. 
https://doi.org/10.2134/jeq2004.0325

Ruibal-Conti, A., Ocampo, C., Adyel, T. M., Hipsey, M. R., \& Oldham, C. E. (2015). Performance assessment of the Anvil Way Compensation Basin living stream: 2004-2013. Cooperative Research Centre for Water Sensitive Cities, Australia, 1-83.

Summers, K., O'Connor, B., \& Fox, D. (1993). Radiological consequences of amending soils with bauxite residue/gypsum mixtures. Australian Journal of Soil Research, 31, 533-538. https://doi.org/10.1071/SR9930533

Summers, R., Bolland, M., \& Clarke, M. (2001). Effect of application of bauxite residue (red mud) to very sandy soils on subterranean clover yield and P response. Australian Journal of Soil Research, 39(5), 979-990. https://doi.org/10.1071/sr97095

Summers, R., Guise, N., Smirk, D., \& Summers, K. (1996). Bauxite residue (red mud) improves pasture growth on sandy soils in Western Australia. Australian Journal of Soil Research, 34(4), 569-581. https://doi.org/10.1071/SR9960569

Summers, R., \& Pech, J. (1997). Nutrient and metal content of water, sediment and soils amended with bauxite residue in the catchment of the Peel Inlet and Harvey Estuary, Western Australia. Agriculture Ecosystems and Environment, 64(3), 219-232. https://doi.org/10.1016/s0167-8809(97)00040-6

Summers, R., Richards, P., Weaver, D., \& Rowe, D. (2020). Soil amendment and soil testing as nutrient reduction strategies for the Peel Integrated Water Initiative. Department of Primary Industries and Regional Development. Perth, Western Australia. Retrieved from https://researchlibrary.agric.wa.gov.au/cgi/viewcontent.cgi?article=1403\&context=rmtr

Summers, R., Smirk, D., \& Karafilis, D. (1996). Phosphorus retention and leachates from sandy soil amended with bauxite residue (red mud). Australian Journal of Soil Research, 34(4), 555-567. https://doi.org/10.1071/SR9960569

Summers, R., Weaver, D., Keipert, N., \& Steele, J. (2014). Does Riparian Filtration Reduce Nutrient Movement in Sandy Agricultural Catchments? Environment and Natural Resources Research, 4(4), 155-168. https://doi/10.5539/enrr.v4n4p155

Taylor, A. W., \& Kunishi, H. M. (1971). Phosphate Equilibria on Stream Sediment and Soil in a Watershed Draining an Agricultural Region. Journal of Agricultural and Food Chemistry, 19(5), 827-831. Doi:10.1021/jf60177a061

Van der Sloot, H., Seignette, P., Comans, R., Van Zomeren, A., Dijkstra, J., Meeussen, H., ... Hjelmar, O. (2003). Evaluation of environmental aspects of alternative materials using an integrated approach assisted by a databaselexpert system. Paper presented at the Proceedings of the Conference" Advances in Waste Management and Recycling", Retrieved from https://publicaties.ecn.nl/PdfFetch.aspx?nr=ECN-RX--03-031

Ward, S., \& Summers, R. (1993). Modifying sandy soils with the fine residue from bauxite refining to retain phosphorus and increase plant yield. Fertiliser Research, 36, 151-156. https://doi.org/10.1007/bf00747586

Weaver, D., \& Summers, R. (2013). Report card on sustainable natural resource use in agriculture. Phosphorus status. Retrieved from https://researchlibrary.agric.wa.gov.au/pubns/17/

Weaver, D., \& Summers, R. (2014). Fit-for-purpose phosphorus management do riparian buffers qualify in catchments with sandy soils? Environmental monitoring and assessment, 186(5), 2867-2884. https://doi.org/10.1007/s10661-013-3586-4

Wendling, L., Douglas, G., Coleman, S., Yuan, Z., \& Klauber, C. (2010). Investigation of Mineral-Based By-Product Reuse for the Removal of Nutrients and DOC from Swan Coastal Plain Surface Waters. Retrieved from https://www.water.wa.gov.au/_data/assets/pdf_file/0018/5094/97300.pdf

Woltemade, C. (2000). Ability of restored wetlands to reduce nitrogen and phosphorus concentrations in agricultural drainage water. Journal of Soil and Water Conservation, 55(3), 303-309. 


\section{Copyrights}

Copyright for this article is retained by the author(s), with first publication rights granted to the journal.

This is an open-access article distributed under the terms and conditions of the Creative Commons Attribution license (http://creativecommons.org/licenses/by/4.0/). 